\title{
Publishing and the Popular Consumption of Print: A Panel Discussion
}

On February 29, 2008, I had the opportunity to sit in on a lecture about the future of academic libraries and the communities they serve. The picture presented was one that had seemed to become formulaic in library discussions: kids don't want to read anymore, they will continue not to want to read, and on the rare occasion that they do read, it will be on their phones. During this lecture, I thought back to a journal I had discovered in graduate school at the University of Wisconsin - Madison. McSweeney's Quarterly Concern, a literary journal that took on interesting physical forms, was popular with the students I knew. I found it on sale at the Student Bookstore and in other shops on the heavily student-oriented State Street. At least in Madison it seemed that reading something in a uniquely physical format was still in vogue among younger audiences. I soon became a subscriber myself and later discovered that the publishing house also offered literary criticism through a publication called The Believer that explicitly sought "to urge readersand, by extension, writers - to reach beyond their usual notions of what is accessible or possible," ${ }^{1}$ as well as a writing program for children (826 Valencia).

The enthusiasm for reading, writing, and physical publications that I felt from these titles inspired me to seize upon the opportunity afforded to me as chair of the 2009 RBMS Preconference and invite a representative from the group to speak to my fellow librarians directly. The publisher of the San Francisco-based McSweeney's, Eli Horowitz, agreed to speak. It was Eli who helped craft the structure of the presentation. Rather than the stand-alone talk that I had requested, he suggested a panel discussion with fellow publishers and editors and offered the names of Tod Lippy, editor of the New York-based Esopus, and Ted Genoways, editor of the Virginia Quarterly Review. When Susan Allen of the Getty Research Institute agreed to moderate the proceedings, a panel was born. In the end, the panel consisted of simply Eli and Tod. Below you will find an edited version of that discussion. For the full experience, please listen to the audio recording available on the RBMS Web site.

$\sim$ R. Arvid Nelsen

1. Heidi Julavits, "Rejoice! Believe! Be Strong and Read Hard!” The Believer 1, no. 1 (March 2003). Available online at www.believermag.com/issues/200303/?read=article_julavits [Accessed 2 March 2010]. 


\section{Panel Discussion}

Tod Lippy: I guess we're here mainly because we are two practitioners of the dying art of producing magazines in the print arena. I think both of us have different approaches as to why that's important to us, but I suspect we both feel there is a lot of promise and a lot of potential still in this waning world, even though we both come at it in different ways.

Esopus was founded in 2003. I started it mainly because I had had a fair amount of experience in publishing special-interest magazines and I wanted to take a different approach in order to create a magazine that would reach a wider audience. So, my idea was to come up with something that was very multidisciplinary in form and content. We have contributions from contemporary artists and filmmakers, writers, poets, musicians - a CD is included in every issue - and the idea was to avoid the kind of ghettoization that comes with specialization in creative disciplines. If you go to a Barnes $\&$ Noble newsstand, you'll find an art section, and a literature section, and a film section, and a design section - the idea was to somehow incorporate all of these in one magazine in order to attract a broader readership. The other several ideas that were behind the founding of the magazine were: I didn't want any advertising. I feel like I'm constantly fighting with advertisers when I'm going through my favorite magazines-particularly these days, when editorial and advertising are so hard to distinguish from one another-and it seemed like it was worth a shot to try to do a magazine that literally had nothing in it that was for sale. So, in order to do that, I created a nonprofit entity, the Esopus Foundation Ltd. We're a 501(c)(3) and we depend on contributions from foundations and individuals to make up for the money we lose from not being able to count on advertising revenue, which, as you all know, is very important in the magazine publishing world.

So that's a just a brief introduction for me and I'll pass it over to Eli, to talk about his adventure.

Eli Horowitz: I work for McSweeney's, which was founded about 10 years ago. We are based in San Francisco and are a small publishing house. We have a few different arms. We publish about 10 books a year-novels, art books, all sorts of things_-and then we have McSweeney's Quarterly, which is mostly short fiction and takes all sorts of different physical forms. We also have a monthly magazine called The Believer and a DVD quarterly called Wholphin. I think today I'll mostly be talking about the quarterly.

Issues of McSweeney's take different forms. Sometimes they look just like books but other times we try and get more complicated. Issue 16 had a comb in it, for no good reason, and included a book of short stories, an Ann Beattie novella, and 


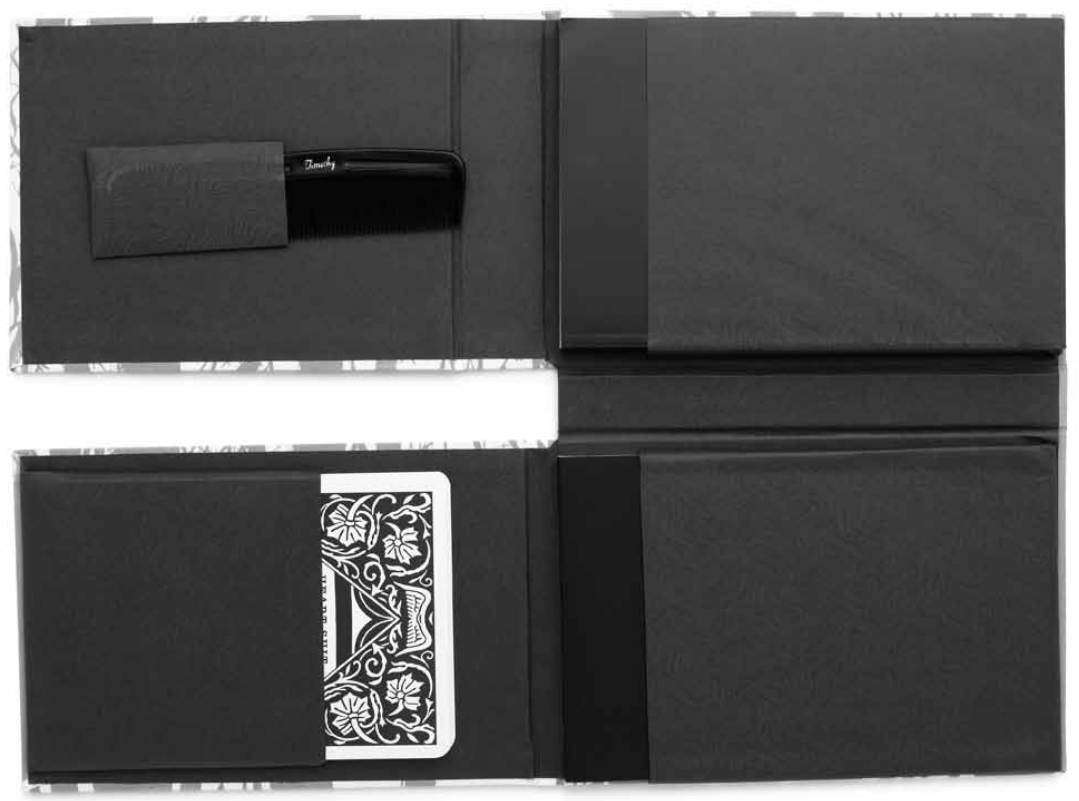

Figure 1. McSweeney's Issue 16

a Robert Coover story that's on a deck of cards that can be shuffled in any order. It's all pockets and it's cloth-bound (figure 1). Issue 19 was like a cigar box of old ephemera: mostly civil defense, an anti-syphilis-in-the-army journal, the stuff that wins air raid instruction, and a bunch of stories. We try to find ways to integrate fiction and design. The book jacket of issue 23 unfurled. Issue 24 opened two ways. The point is we try and redesign it each time, to do something different with it. Sometimes the form drives the content. Sometimes the content drives the form.

We also have been trying to reinvent the literary journal in a certain way; not really in a conscious or ideological way, but to let what we're excited about guide what we do rather than preconceived notions of what journals can be. I think particularly in the world of literary journals, and often probably in the arts magazines, there's an attitude that it should exist. It's like "eating your vegetables," or it's just "defending the fort against the world that clearly doesn't care" and you fight the good fight. We tried not to start from that point. This was going to be an exciting thing that we care about and I think that really spreads to our readers and our audience.

Something else that Tod has done especially well and we have tried to do, too, is make it inexpensive. An issue of the Quarterly costs maybe $\$ 15$ to $\$ 24$, and that's really important because we see these not as special art objects for collectors. We want kids to be able to buy it. And so Esopus is $\$ 10$ dollars, or something? 
TL: It was $\$ 10$ until our 11 th issue. We finally came to the conclusion that we couldn't quite handle that enormous discount, so now we're \$14. But it's still much less than it costs to produce for each issue. That also reflects the whole mission of getting the magazine to a broader audience. I agree with Eli completely, we're not making it for ... I mean, I love that book collectors and people who appreciate objects, and books as objects, are interested in it, but I want it to be on newsstands and in Barnes \& Nobles in Tulsa and Belgium and everywhere else so that it's very easily accessible. That's very important to us.

We've done only 12 Issues-we're a little younger than McSweeney's. One of the goals I set for myself as a designer was that I wanted to be as invisible as possible. We never include any text on the covers-no cover lines, no information about what's inside the magazine-and the point is hopefully to engage people enough that they will be encouraged to open it up and take a look. The backbones of each issue are three artists' projects. Issue 4 featured one by Ed Ruscha, where he altered a bunch of book covers and they appeared throughout the issue. Issue 8 included one by Neil Goldberg. It's a series of video stills of people who just missed the subway in New York. An artist project by Beth Campbell in issue 1 folds out. We try to do lots of things, just like McSweeney's, that don't necessarily feel like a magazine. We often feature inserts that are meant to be removed from the magazine. Issue 3 includes a Jenny Holzer project that features declassified documents, the Albert

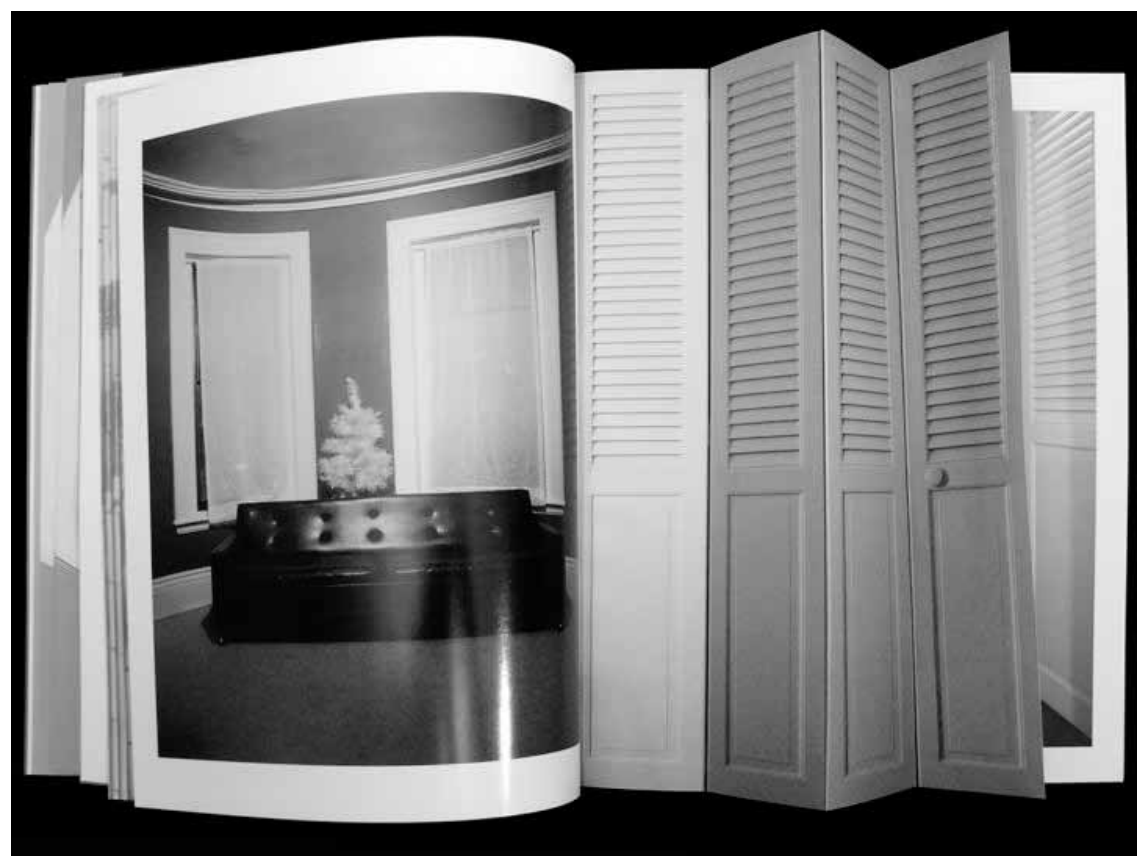

Figure 2. Esopus Issue 9 
Gonzales memos about Abu Ghraib, and we published them in ink that is photochromatic so that it actually activates once it's exposed to the sunlight. It was quite a challenge to print, but a lot of fun to do. Issue 9 had a Sarah Malakoff project. We try to incorporate things into the magazine that can be folded and manipulated in interesting ways (figure 2). The Berend Strik project in issue 10 was a hand-sewn edition. The Robert Therrien project in issue 11 included removable inserts, so that kind of thing. The idea is to make it feel as if you're opening a box of objects that all have their own thing to say to you and don't necessarily fit a particular magazine format. Unlike McSweeney's, we don't change our look with each issue. All the issues have the same dimensions and trim sizes, because I'm a bit of a control freak about that kind of stuff, but the idea is the same: to make each issue feel like an entirely new thing that doesn't look like the latest edition of The New Yorker-which I love, by the way. But they're doing a very different kind of thing from what we're doing.

EH: Obviously, there's always a question of what should be electronic and what should be digital—and what shouldn't be. For McSweeney's, we've had an online component since the very beginning — since 1998 actually_and it's definitely served us really well. It's been important in terms of building community, and that's an important part of what we do. But it's also important to us to keep doing these things in print. It's not out of any rule, ideological defense of print, or anything like that. It's just something that excites us, having a physical object, but we're always really conscious of having to earn it. That's the way I think of it: if it's going to be printed, there has to be a need for it to be printed. There has to be a necessity so we never get into ... well, if someone starts talking about the smell of the page or something, I am not so interested in that. Of course, we're still doing things like combs and magnets, so there's plenty of nonsense involved, but we're always trying to really earn it. We're saying, "How is the fact that it's a physical object fundamental to the experience of this thing?" There are plenty of things that probably should be electronic and we do some things that are electronic - there's still a place for both. Certainly in our readers' experience, there is still a real excitement about picking up an object, and I think the rise of the Internet and online narrative only intensifies the excitement that you get when you open up an issue and the ink changes color. That's an experience you fundamentally won't have in other formats. And so it's not this either/or, print or digital experience, but rather figuring out the confines and the possibilities offered by that form and talking advantage of it to the fullest.

TL: I agree completely. I think it's very much about recognizing that there are certain things that are imbued with a certain aura, to be a Walter Benjamin type about it. But even though these are all mechanically reproduced, I want to give people the sense when they're opening the magazine that they're actually looking at some original object, whether it's a piece of paper, or a pop-up, or a business card, or something 
else that's sort of fallen out of the magazine. We have an online presence as well, but it's very minimal. Our first seven issues are sold out, so we've put most of the content from those issues online. But essentially it's really just for us. It's a much different approach than McSweeney's, which has a much more elaborate and impressive Web site than we do. We're using the Web site basically just to give people a sense of what Esopus is about and of course to offer them an opportunity to subscribe to the magazine. But I can't imagine ever doing any of this online because it really is about the tactility of the objects and the material within the magazine. I think there's still a huge audience for this kind of approach. Our circulation is certainly not enormous, but we sell out almost every issue and we count enthusiastic readers, young, old, in between.

We have subscribers in 49 states. But I really do believe ... I don't think it's some kind of survival thing at all. I think there's always going to be a market and an interest in this kind of publication, a print publication. And yes, it may be a more narrow kind of field within which you're working but ... maybe I'm just a bit of a Luddite, but I think that print is here to stay, just in a very different form, perhaps.

EH: Well, there's a space for both. I mean, plenty of things that are currently printed should be online and will be online and shouldn't be printed. Because what's the point, you know? People complain about eBooks as an entity. But 80 percent of books are junky, ugly things. So, if you can make them smaller and cheaper, why not? But there's still an important experience that can be had with physical objects, and so it's a matter of really seizing upon that and taking advantage of it.

Susan Allen: I just was going to see if I could ask some questions and maybe elicit more of a response from you and then we can see what people want to ask from the audience. I guess, Tod, I'd really be interested in knowing why you ever thought that you could do a magazine without ads. Whatever possessed you to think that it would be possible to do that?

TL: Blind optimism.

SA: Tell us more about that experience.

TL: I came at this with an enormous amount of frustration, not only as a reader but also as an editor. I worked at a design magazine and a film magazine and dealt with a very mild version of the pressure from advertisers and publishers that I'm sure editors at Vogue and everywhere else are overwhelmed by—namely, to tailor content to whoever is buying the biggest ad that week or creating advertorials or things like that. But I was convinced it was not worth doing another magazine if I couldn't do it without advertising. Having worked on several magazines in the forprofit world, it seemed clear to me that I was never going to be able to bridge that 
revenue gap-I mean, frankly, depending on advertising revenue if you're most arts publications is ridiculous anyway. So I just knew we would have to do the 501(c) (3). As it turns out, it's actually been a very valuable way to garner contributions and foundation grants, because you have a very simple balance sheet: this is what it costs to produce; this is what we're selling it for; and this is this gap we're facing due to the fact that we're not getting any other kind of revenue and we're very limited in our means. And I think it's been more helpful, in some ways, to be a purist about it. It's worked so far — knock on wood—but it was a bold, or even potentially stupid, kind of move to make. But I just thought it wasn't worth doing otherwise. It just felt like it would be a deadening kind of experience otherwise.

SA: It sounds like you really believed that what you were doing had to be done that way.

TL: That's absolutely true.

SA: Well, Eli, I have a question for you, too. I think the ambition to have each McSweeney's be different from the one before, different design and so forth ... How did you come to that? Why did you come to that? And who's the creative force? Are you totally the creative force or are there other designers involved?

$\mathrm{EH}$ : I think the reason it happened is just a sense of possibility, the same things Tod is doing, just sort of wondering, "Can this be done?" and "What would happen if we did this?" And so sometimes we have the idea for a physical format long before we have any reason to do it. A little while ago we did a magnetic issue where there were three books held together with magnets. They're very strong and expensive. And we had the idea for this magnetic issue probably two or three years before we did it. We were just waiting for a reason. So basically we're just keeping ourselves amused. You just sort of wonder, "What would happen if we did this? Could this be done?" And then you investigate it and then it opens up a whole world of possibilities. I guess it's a pain and we definitely take issues off. Issue 30 was just a soft cover, and we kind of acted like it was a throwback to the design of early issues. It was also just easier. So, it comes and it goes. We need a break, definitely, often. They're not all as ridiculous as the ones I showed. But it's more fun. It's more fun for us and more fun for the readers and the audience and I think that's a necessity.

Who's the force? McSweeney's was started by Dave Eggers. He was doing it alone for the first year or so, the first few issues. I came on around issue 9. It depends. Sometimes I'll do one and he'll do one or there's a collaboration. It's a really small group of us who do all of them. The editors and designers are always the same people. That helps create a closer link between the content and the form. 
TL: That's really important to us as well. I'm the editor and the designer and I think it happens very rarely in the publishing world. Certainly with McSweeney's you see this seamless kind of collaboration between content and form and that's very much my goal as well. Another frustration I had working at other magazines was, as an editor, I would solicit an article, work on it with the authors. They would submit visuals. We'd talk about what was important and we'd send it off to the art director and it would come back and completely ignore the emphases the contributor had made. It was always so demoralizing. I felt it would be nice to literally control every aspect and therefore have total responsibility for it working or not working. It's been enormously rewarding. It's very challenging at the same time, but at least you know that you are the point person for everything that's happening. And I think, certainly in McSweeney's case, it's led to amazing things.

EH: It's partly knowing the work better and being able to respond to it also on both sides, but it's also being able to get out of the way. I think a lot of times what happens is that the designer is just sitting there waiting to get the content, then they get the content and it's their time to shine. So then they do some nonsense, like an enormous drop-cap - the story starts with a " $G$ " so the $G$ is 6 feet high, screened out over the whole page. And it's not like the story is about "G." They don't want just to pick 11 point type and make that the whole thing. It's their time to be a designer, and that's understandable, but we can get our energies out in different parts. Sometimes it's more intense in one direction or another and we don't need to put our fingerprints on everything.

SA: One of you said that you really want to reinvent the literary journal. Was that you, Eli?

EH: I take it back.

SA: Well, that's my question. Why do you want to reinvent the literary journal? Why do you think you can?

EH: Those are both good questions. I wouldn't say reinvent. Certainly, we never have conscious goals like that. It's more that we were excited about what we were doing and we tried to bring an energy to it without necessarily worrying about the pre-established models. There are definitely plenty of other magazines that do a great job, plenty that have been really important in keeping the idea of a literary journal alive for all these years. What we just didn't want to... If you're a literary journal, you're maybe associated with a university. You sell maybe 800 or 1,500 copies and you don't really believe you can sell more because you really can't sell more. If you try to do something funny, someone is going to get mad at you, someone 
who's funding the thing. It becomes, again, this sort of "eat your vegetables" or ghettoized sort of thing. So, it wasn't so much about trying to change that model as just trying to not be confined by that model, or just ignoring that model and saying that we're excited by these stories, we're excited about this object, and trying to communicate that excitement to the reader. If we have stories we care about, let's try to put them in a format that honors them. It's not really historical overthrow as much as just trying to make it new, I guess, and start fresh.

And why do we think we can? I don't know. It wasn't that hard, I guess, is the main answer. A little excitement goes a long way. A lot of the design things we're doing are "just because." I was not trained in either editorial work or design work. People can really feel you being excited and trying to do something different. And we make huge mistakes in every issue and every time I get something back from the printer there's something that I realize I messed up, but people are ready to be excited and it doesn't take that much.

TL: I agree completely. We're not a literary journal. We feature fiction occasionally and poetry occasionally, but Esopus is much more about visual essays and artists' projects, things like that. But I wasn't looking at literary journals, thinking, "Well, I'm not going to do that." I was literally thinking I'm going to do something that I wanted to do that feels viable and excites me and makes me enthusiastic about the whole process. I mean, one of the big problems with Esopus is that it's not really a literary journal. It's not really an art magazine. It's not really a film magazine. So, you end up in the gardening section of Barnes \& Noble sometimes because distributors don't know what to do with you. One of the major issues you have to deal with as a magazine publisher is that you have to rely on someone to take what you've made and distribute it to the public. That could be a whole other topic for a panel of enormous frustration and angst. But if you're a literary journal you end up in the literary journal section of Barnes \& Noble—and I don't see McSweeney's there. Where does McSweeney's end up?

EH: McSweeney's is basically sold like a book, rather than a magazine. It's harder for magazines and when we do stuff like that it's a huge pain. So an advantage of us having this different weird format and looking clearly not like a magazine is that people will treat us in a special way, whereas they don't know what fun stuff is inside, usually.

SA: It occurred to me that your work reminds me of artists' books; only artists' books are often in very small editions. Sometimes they're actually unique copies. But they do have the form reflect the content, and the content impacts on the form, and so forth. At some point, Eli, you said you weren't interested in the smell but then you seem to be interested in all other parts of the experience. 
EH: I'm interested in the smell if it's an interesting smell.

SA: Are you making artists' books?

EH: I would love to do an issue where each story has its own aroma, for example. But I would say artists' books should be overthrown. Just as much as literary journals or art magazines need to be renewed and reinvented I would say artists' books, too. And the idea that there are five copies of something ... it just seems depressing a little bit to me. If you want people to see it, why not make something that can be seen? It's also using these preexisting models and-particularly when they are economic models that are imprinting themselves on the art object-it seems depressing. Not even getting to these five-copy things but I'll often see things in museum shops that are like the artist's monograph for $\$ 50, \$ 60, \$ 70$. They make it that price and they know they're gonna sell maybe 700 or something, so they print 1,000 copies. You print 1,000 copies for a fancy book you're going to be paying something ridiculous like $\$ 15$ to print it. So, it's a self-fulfilling prophecy and then you need to charge $\$ 50, \$ 60, \$ 70$.

We might think, "Hey, we believe that people, normal human beings without lots of money, are going to be interested in this thing we're doing because we're human beings without money and we're interested and would like to have this. So, let's print 4,000 copies of this. Let's make it $\$ 25$ or $\$ 29$." Still more than we'd like but, you know, a reasonable purchase. So, we sell 3,000 of those 4,000 or something, and it works out. We don't really make money but at least we made something that was out in the world and I think that's important. I understand that sometimes things have their own reasons for being small but I think that something really central to what we're both doing is that we're not making it for someone who's not going to be able to open it or take it off the shelf or not be able to afford it. We're making it for human beings.

TL: Not only that, but I think there's a real optimism on both of our parts. I think that there's a significant audience that contemporary art, which has very neatly and comfortably created a niche for itself, isn't reaching. It's a niche that's basically dictated by a market: The more elite and the more inaccessible the work is, the better the market does. It sounds kind of cynical but it's basically true. So, featuring artists' projects by contemporary artists who are not known outside of a very specific kind of art context, like Jenny Holzer or Robert Therrien or Richard Tuttle, and choosing not to introduce them with a critic's interpretation - "This is a piece by Jenny Holzer. She's a conceptual artist who often uses language. In this piece, Holzer has referenced ... blah, blah, blah" - is essential. We just literally present the artists' projects on their own terms and that, to me, speaks to that optimism I feel about people being much smarter — and more open-minded—than they are given credit for. 
For instance, the Jenny Holzer project with the photochromatic ink appeared to be just 16 blank pages in the middle of the magazine. It was our third issue and we'd just started to sort of get out beyond New York, L.A., San Francisco. And I got a number of e-mails from readers saying, "My issue's defective because it has 16 blank pages." In the table of contents, all we said was "These recently declassified documents must see the light of day"- that was it. How much better to have someone figure it out on their own and offer them this phenomenological relationship, give them an actual stake in declassifying these government documents. So, even though I was kind of disappointed and maybe even a little alarmed that some people hadn't figured it out, I was also thrilled because it meant that we were reaching an audience that didn't know, "Oh, Jenny Holzer. She's exploring another crazy new medium in this project." That to me was an example of the optimism. Even when there are some people who are like, "Heh? I don't get it," there are others who are thrilled and perhaps even say, "Wow, that's something that taught me a new thing about existence, or politics, or whatever."

EH: I think that "optimism" is a much better way to say it than I've been saying it. It's just sort of a belief that there's a hunger out there, and we're not even talking about a real hunger with millions of people. We're talking about 10 or 20 thousand people, but that's enough to make a viable mass media publication. So, it's that belief that you can speak to a wider audience and that people will care. And I think we definitely both have all sorts of financial and practical troubles constantly, but there is a group of people out there who really care and who really get into having these things speak to them and being put in a format they can actually acquire and experience.

SA: I want to ask, why the online presence? You're both so dedicated to the physical and to the print and it sounds like you're actually having some interaction with readers through the online presence. Is it really just for marketing? Why are you doing that?

EH: We, from the very beginning, had almost daily content starting even in '98 or '99 on our Web site. Short humor pieces. Why? I don't know. For the same reasons that the Internet is a good thing. I mean, the Internet is a good thing. And so you can put things up faster. If you have an idea, you can get it out there right away. We have maybe 100,000 different people each week at our Web site. It's a way to speak to a larger group, and then some number of those people becomes fans of us. We can also sell our work directly without going through normal distribution channels, which are always a pain. If we have an event we can announce it right away. We can put out a book, a physical object, but you can respond to it in certain ways or we'll have various contests or games that are connected with a physical object that have a Web component. So there are all sorts of things and, like I was saying before, I don't see us as specifically defenders of print or defenders of the object. We try 
and explore different media, and each one presents its own possibilities and so we do things online that we could only do online, and we do things in print we could only do in print. But definitely a key part of McSweeney's existence has been our ability to reach a wider audience, to speak to people directly and not be trapped by normal distribution and publicity channels. So, even though we're this kind of old fashioned print company, our existence has been totally dependent on new media.

TL: It's pretty much exactly the same thing for us, except on a much less elaborate scale. The Web site is great for us to be able to sell magazines directly to readers, to sell subscriptions and artists' editions directly to readers. It's also a great way to communicate with your audience, again. Let them know about events, that kind of thing. We often do subscriber invitationals where, for instance, we'll ask our readers to submit descriptions of their childhood imaginary friends, which we then give to musicians, who write songs about the friends. So it's great for that kind of stuff. And it's very inexpensive. It's a great way to keep in contact with your audience and also to reach an audience all over the world. All you have to do is log on and you're there. You don't have to race around trying to find a copy of the issue. It's pretty much just an accessibility and convenience thing for us.

SA: In 50 years, where would you like Esopus to be?

TL: Oh my, I just hope it's still around. It's probably going to be dust by then. We don't print cheaply. We have a wonderful printer and we spend a lot of money on printing, but I'm worried that it won't hold up—and maybe that's okay. Maybe that's part of the whole process. I'd like to see it in the collections of everyone's institution that's represented here today.

SA: I was wondering about that, if it is in special collections departments.

TL: I love knowing that the magazines are in a place where they will be protected and seen by a lot of people, someplace that offers access to a wide group of people. The magazine is not meant to be tossed in the trash. It's heavy. There are six or seven different kinds of paper stocks in every issue, different kinds of inks, posters and things like that. The one place I don't want to see it is in a garbage can. That would make me very unhappy.

SA: How about McSweeney's? Where's it going to be in 50 years? You fellows are young. You're going to be around.

EH: But our life force is short. I think on a logarithmically different time scale than that. But we are doing the same thing as Tod said. Trying to make an object 
that people want to save, I think, is fundamental to what we're doing. If we don't want to end up in the trash, we have to make something that shouldn't end up in the trash. But, it's such a mess just trying to run a company with all of us incompetent and just ridiculous people, so if we're around in 50 years it's a miracle. We don't really know what we're doing with getting into special collections or speaking to this whole world, except for now. So, any advice would be appreciated.

SA: Well, this is probably a good time to see what kinds of questions all the special collections librarians have for you.

Question 1: I'm a rare book cataloger and I had the very interesting task of cataloging 51 issues of a magazine called Visionaire, which is - supposedly — where art and fashion meet, and each issue is sponsored by a corporate sponsor like De Beers, who sponsored an issue with a real diamond in one copy, and Levi Strauss who sponsored one that arrived in a custom-designed denim jacket that could be worn by the subscriber. I mention Visionaire because they also are trying to expand what a magazine is like, even if it's in kind of ridiculous ways-ridiculous and fascinating-but I'd be very curious to hear what you think of it.

EH: I think it costs like $\$ 660$ dollars for a subscription of 4 issues.

TL: I love Visionaire. I think it's beautiful. But asking a diamond company to sponsor my issue and then fashioning an issue around it involves a creative flexibility I just don't possess, unfortunately. But I do think what they're doing is amazing and inspirational, frankly. I have a couple of the issues that I got in exchange for other things way back when and I treasure them.

EH: I would agree with both halves of that. They did one with a record player where it had a little car that could drive around the record and it would play the record. So, yes, they do amazing things. Although, definitely half of our art-to whatever extent we have art-is working within a budget, and getting to know how a printer works, and figuring out how to get the most bang for our buck.

Question 2: I'm interested in a couple of things: 1) Your sense of history, whatever you want to say about that would be great; and 2) How do you construe not only who you try to reach but who you pull in. And what I mean by that is that one of the functions of some academic journals is to find new voices and give them a place.

EH: First of all, the University of Illinois actually has a great journal, Ninth Letter, which is another one that's come up a little bit after us but is a real example of bringing a new energy to these things. And the same with Ted Genoways and 
the VQR here at UVa. So, there are a lot of these university journals that really are doing a lot of great work and taking up this kind of enthusiasm and so I am excited about this whole generation of people doing that.

Sense of history ... I think, probably as a practical matter, we're somewhat ignorant of it. But we definitely see ourselves as in a lineage of this, to some extent, but trying not to be bound by that lineage. There's this Fluxus magazine, Avalanche, I think, that I was looking at recently, that I was really impressed by. There's definitely this whole history of what we're doing but I think, to some extent, too much awareness of that can be limiting because you're too conscious of your own mortality and limited scope. So there also has to be belief that you're doing something new and that you're the first one ever to do it. Of course, you don't really believe that.

In terms of new voices, definitely, that's crucial to what we do. And so, basically, we just get a whole stack of manila envelopes. They all go on this baker's rack. Everything gets read. And so, at least half of what we publish just comes to us randomly, unsolicited, and that's always been really crucial to us, from an editorial standpoint.

\section{SA: And Esopus?}

TL: Same thing, pretty much. We're very devoted to featuring emerging voices in art, and film, and music. I'm just going to give you a few examples. Issue 4 featured an amazing sculptor named Ulysses Davis whose work I came across in Savannah when I was there one year at Christmastime. He died in the late ' 80 s but was not very well known. He carved busts of every U.S. president and he displayed them all in his barbershop. We did a big, pull-out poster of all of these incredibly, beautifully, gently subversive takes on the presidency and citizenship. Issue 7 featured a 13-year-old named Alex Brown who does these mesmerizing battle drawings-again, somebody who came to us through weird channels, who'd never shown his work before. He's since gone on to show in a couple of galleries in New York. Issue 10 featured Robert Guest, an exhibition designer who has written each of his two kids an eloquent, deeply felt note every morning since they were in pre$\mathrm{K}$. They're really, really stunning things. So, yes, we're very devoted to emerging voices.

As far as a sense of history is concerned, there are so many precedents. Artists' books, as Susan suggested, are really an important inspiration for me. Also Portfolio magazine, which was a brilliant magazine with Alexey Brodovich as its art director, creative director; Audience magazine; Horizon, the Time-Life hardbound magazine from the ' 60 s and '70s. There's a huge, huge range of things. 
EH: One other thing I'd add is that the sense of community is really important to us, and having various concentric circles of involvement. And, coming from San Francisco, there's this whole City Lights and Beat precedent, which we don't necessarily connect with aesthetically, but just the idea of a circle of friends creating something. Combining that with the Internet and so forth has been really useful, so it can have community without being cliquish or limited and anyone we see online or who e-mails us can also be a part of it.

Question 3: The National Gallery recently had a large exhibit of Dada art after World War I using modern technology, at that time, in order to have sort of an antitechnological feel. I'm wondering if either or both of you are actually Dadaists in disguise.

TL: I have a portrait of Marcel Duchamp in my office. He is my god and my hero, so yes, absolutely.

EH: I think that spirit is in all of our work, and I'm sort of this, maybe, Dada Rationalist, in some sense, where at first it has no reason and I convince myself that the comb is extremely necessary and vital, and hopefully that adds some sort of dynamic tension, hopefully.

Question 4: We've heard a lot about the fact that Esopus is a nonprofit and you give a great deal of credit to your donors in the magazine, but we haven't heard about the fact that McSweeney's publications also all appear without advertising. How do you make up the difference? How do you survive?

EH: Well, not well, is the main answer. The Quarterly has no ads. The Believer, our monthly magazine, as of a year or so ago does have a few ads per issue, which is a pain to think about even. How do we do it? We are poor. We have a very small staff. We do some books. Every now and then a larger, bigger name author like Nick Hornby or Michael Chabon will do a book with us, whether for fun or because it has design specs that wouldn't fit well with a larger house. And those help us survive. Then, again, just being very poor is always a good strategy for not going out of business. So, it's hard, but it's not that bad because no one would really want to advertise in this thing anyway. You know? I mean, it's like 15,000 book lovers. Where's the money in that?

SA: So, you're saving yourself time and frustration.

TL: Particularly with smaller arts magazines and literary magazines, it's depressing to look at the ads, because you know they're all trades. They're other literary magazines or they're publishers, or they're restaurants where they give you a free ham- 
burger if you go once a month, or something. My feeling is, why cross that line if you don't have to, considering the paltry amount you're going to get for the ads you run.

Question 5: Two questions for you: How much were you inspired by zines, which I think are some of the most democratic, local, charming, and future rare fugitive materials that we can have now of contemporary materials in special collections? And have you made provisions for your own archives?

TL: As far as making provisions for archives, no, we haven't. Zines were very important to my formation as a magazine editor and designer. The first, basically adolescent version of Esopus that I did in the early '90s was called publicsfear and it was a zine. It offered a real way for me to work out what I wanted to do later on with this magazine, which is resolutely not a zine, but I agree completely. I think it's something that wouldn't exist without that precedent. The freedom that comes with being able to do your own thing - not worrying about fitting into a niche but rather creating your own niche, being very personal in your approach to things-is wonderful. I mean, the only other thing that I would say is very zine-ish about Esopus is that we have no contracts with our contributors. It's an editorial policy I instituted, also based on frustrations I'd had earlier on while working at other magazines. I never deal with anyone but the artists, writers, and musicians I hope to work with. So, I don't call agents or gallerists, and I never deal with managers or publicists. And that has been an incredibly wonderful thing on many levels.

EH: Yes, I agree. It's been really important, and I think you're right. That's very much where the flowering of individual culture is happening. I don't know if that's represented in any of your collections at all, but it seems to really make sense. I think we've actually lost some of that spirit, to our detriment. Some of the unpredictability, even though we're sticking things in it, but that kind of mish-mash of forms and contents and that intensely personal vision, we've lost a little bit as we've become slightly more respectable. I think Tod still has that and maybe he'll lose it soon, too. But I agree, it's very important, particularly in San Francisco where we come from, but in New York also, I guess. There's a strong zine culture still and there are even stores devoted to it. I think there's also this rise of an indie crafting movement in bookmaking and things like that and I think they all play together in an interesting way.

SA: And what about your archive?

EH: It's in our basement.

Question 6: I want to bring into the conversation our missing panelist, Ted Genoways, and the Virginia Quarterly Review and a question particularly for you, Eli, about 
editorial content and working with authors. I know you have published some of the same authors. Speaking of fiction, Joyce Carol Oates and Art Spiegelman have appeared in the pages of $V Q R$ and in a very different setting with you and maybe you could bring some of what you know. What are your authors' responses, working with them and their excitement over publishing in your journal versus others?

EH: We definitely have a lot of overlap, the people you mentioned and also Lawrence Weschler, all sorts of people. I think authors really enjoy it. We give them a lot of editorial attention, and I think they like that. We're very respectful of ... you know, it's fine if it's a long piece, fine if it's a short piece. The piece always takes precedent because the form is so flexible. We don't have to dictate things for other reasons or say, "Oh! But two issues ago there was also a piece with a horse in it, so ..." So they like that, but I think what's more distinctive to their experience about us is it's sort of exciting to them to feel like part of this collective movement and to exist within this context of other things. Whereas they might have had their story in The New Yorker and I'm sure that was exciting in its own way but there's a certain surprise when they get the issue in the mail and they see that now they're part of this weird folding thing or they're next to this totally different kind of writing. I think the writer's world can be very cloistered and also kind of lonely and it becomes predictable in a certain way.
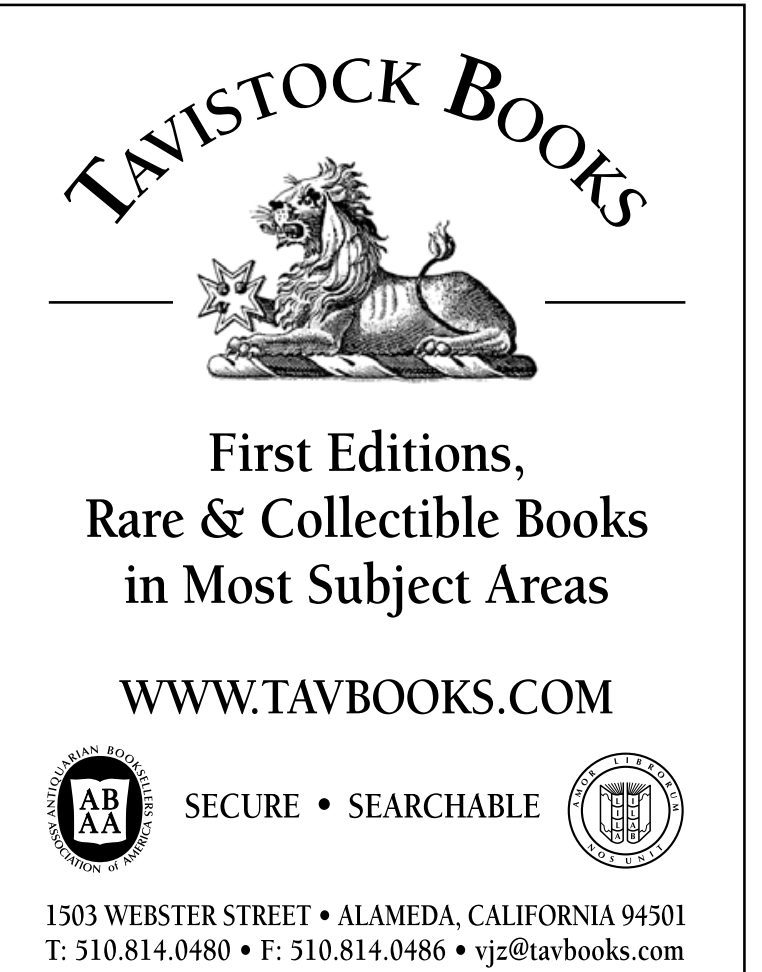
Even when it's successful and rewarding it becomes predictable, and I think they enjoy suddenly parachuting into this other world.

SA: Tod, anything about your authors that you want to say?

TL: I think it's very similar. We're kind of an oddball sort of thing that comes out of left field, and most authors or artists I've worked with seem to be very game to give it a shot, maybe because it's very, as you said, hands-on, and there's no, "Oh, your agent suggested that you would like to da-da-da-da-da." You're dealing directly with the people that are going to make the contribution, and there's a lot of back-and-forth. There's a lot of fun. I'm very keen on making sure whoever contributes something sees the last version before it goes to press. They can make changes. It's a very collaborative relationship and I think people, although they're not getting the exposure they get in The New Yorker — or McSweeney's, for that matter — know that at least what they contribute is going to end up exactly in the form that they want it to be in.

Question 7: I was thinking the same thing about artists' books. I've been to some book fairs where I can walk in but I can never buy anything. So, what interest me are price and affordability and, on the one hand, how these [Esopus and McSweeney's] look really creative and, on the other hand, whether there are commercial or practical issues that you've been forced to deal with just in the matter of doing business. I used to work at a magazine in a past life and we had all these rules about what would go on the cover and then how many issues we would print as a consequence, so like Britney Spears trumps Donald Trump. And I'm just wondering where you have had to toe the line and say, this is the limit of what we can do: seven stocks of paper, not eight, or Britney Spears over Kelly Clarkson.

TL: We share the same printer for some, not all, McSweeney's; I guess the paperbacks are usually printed at the same printer I use, as well as The Believer. And a lot of the ways we've cut costs relate to the printer's ingenuity. We did a pop-up with the artist William Christenberry in the second issue. We approached several paper engineers who gave us quotes for designing and fabricating the piece that were more than the entire budget for the issue, and I was about to give up. But the printer said, "Let me ask the ladies at this Hutterite colony in Winnipeg." It turns out these women assemble things very cheaply—and meticulously. They've done stuff since for the magazine - in fact, they hand-sewed that Berend Strik project I mentioned you earlier. So it's very much about being crafty. It's about asking for donations. We solicit donations from paper companies for every issue, for instance. And occasionally, of course, you just can't do something because it's too expensive- - that's where the limitations come in. But as far as content for the cover for either of us being a reason or not a reason to do a magazine, it just doesn't really happen that way for us, luckily. 
EH: For McSweeney's we just don't worry about it. Because I'm officially the publisher of The Believer, one time I sat down and I looked at the sell-through rate, which is basically how many sold of each issue, and I wrote down the names of the people pictured on the cover. There are no pictures but there are drawings of four people of every cover. There was no relationship at all, even when we had Kelly Clarkson. No, we haven't yet had a Kelly Clarkson interview, but someday. Yeah, part of it is getting crafty and something that's really important to us is working with a printer, developing a relationship with a printer, getting a sense of what they can do cheaply and what they can do expensively, and it's not always logical things. A lot depends on what vendors they have for certain materials, what machines they have that print certain things. So understanding how that works has been really important. I'm actually going to Singapore, where we do a lot of our fancier things. I'm going there in August to learn even more about their setup.

Q: You know India is cheap when you want to outsource.

EH: I heard. I heard. Actually, even our Singaporean printing outsources their handwork to Malaysia. But I would love to print in India. I don't think they actually have that much of a printing background yet, but definitely.

Q: They can sew.

EH: They can sew. That would be good. That is true. Maybe a fully textile issue would be good.

SA: I'm afraid that we've run out of time. This has been a tremendously enjoyable and enlightening discussion and I thank you very, very much for being here today.

\section{INDEX TO ADVERTISERS}

ABAA

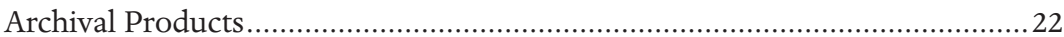

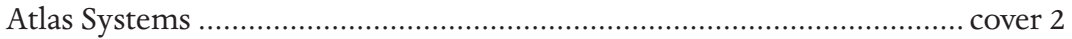

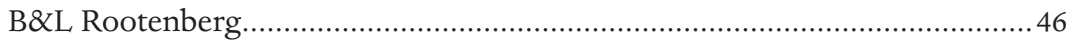

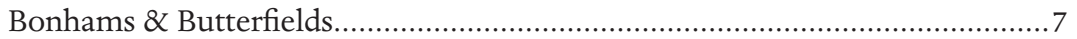

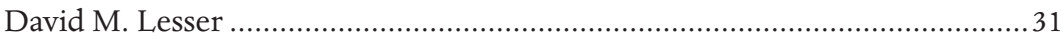

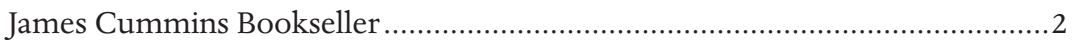

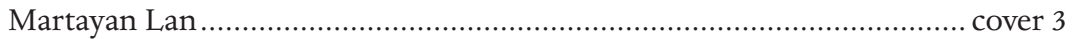

Philadelphia Rare Books \& Manuscripts ................................................... cover 4

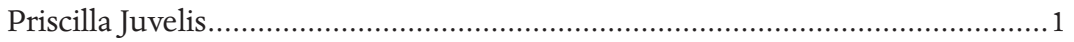

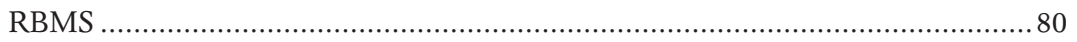

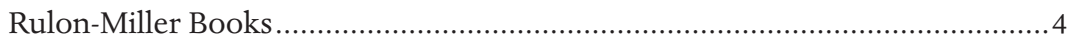

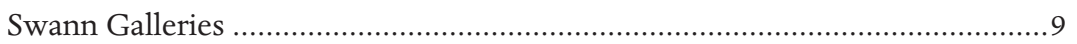

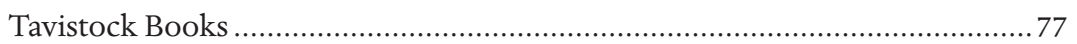




\section{5lst Annual RBMS Preconference Philadelphia, Pennsylvania June 22-25, 2010}

JOIN, or DIE. Collaboration in Special Collections

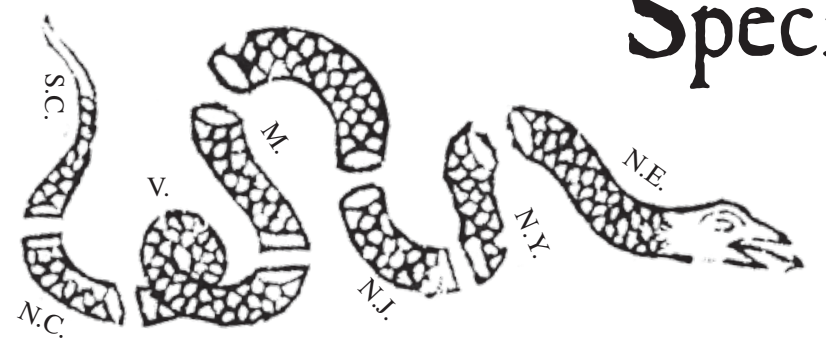

With major sponsorship from the Philadelphia Area Consortium of Special Collections Libraries (PACSCL)

In our current economic climate, the theme of collaboration seems an especially timely one. This preconference will explore collaborative relationships as broadly as possible: with our coworkers and our colleagues; with scholars and students; with donors, funders, and vendors. In short, our subject will be any instance in which we can accomplish more by working together than we could alone. A variety of workshops, seminars, case studies, discussion sessions, tours, receptions and a booksellers' showcase will complement the main program.

Registration and housing are still available! Late registration charges apply after May 19. For complete details and registration materials, visit: http:/ / rbms.info.

\section{http://rbms.info}
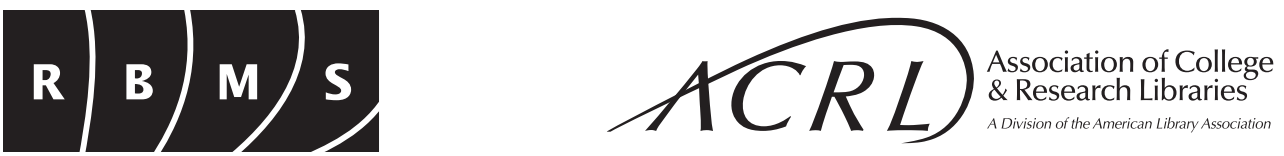